\title{
Law and Peace
}

\section{Contracts and the Success of the Danish Dairy Cooperatives}

Henriksen, Ingrid; Hviid, Morten; Sharp, Paul Richard

Publication date:

2011

Document version

Early version, also known as pre-print

Citation for published version (APA):

Henriksen, I., Hviid, M., \& Sharp, P. R. (2011). Law and Peace: Contracts and the Success of the Danish Dairy Cooperatives. Department of Economics, University of Copenhagen. 


\section{Discussion Papers \\ Department of Economics \\ University of Copenhagen}

No. $11-11$

Law and Peace: Contracts and the Success of the Danish Dairy Cooperatives

Ingrid Henriksen, Morten Hviid, and Paul Sharp

$\varnothing$ ster Farimagsgade 5, Building 26, DK-1353 Copenhagen K., Denmark

Tel.: +4535323001 - Fax: +4535323000

http://www.econ.ku.dk

ISSN: 1601-2461 (E) 


\title{
Law and peace: Contracts and the success of the Danish dairy cooperatives ${ }^{1}$
}

Ingrid Henriksen, University of Copenhagen

Morten Hviid, University of East Anglia

Paul Sharp, Humboldt University / University of Copenhagen

\begin{abstract}
We consider the successful early emergence of cooperative creameries in Denmark in the late nineteenth century within the framework of the 'new institutional economics' presented by Williamson (2000). Previous work has focused on the social cohesion of the Danes, but we demonstrate that this was not sufficient for the success. The Danish legal system, which we compare to that of other countries, was also of crucial importance, along with the way in which rules were monitored and enforced. Of particular importance was the Danish cooperatives' use of contracts, which we explore with evidence from a variety of primary and secondary sources.
\end{abstract}

Keywords: Cooperatives, creameries, contracts, new institutional economics

JEL codes: K12, L31, N43, N53, Q13

\footnotetext{
${ }^{1}$ Financial support from the Danish Social Science Research Council, grant no. FOR890 and the Carlsberg Foundation is gratefully acknowledged. We thank Martin Bork and Susanne Krogh Jensen for very conscientious research assistance. Earlier versions of this paper were presented at the 74th EAAE seminar, 2001, the 4th EHES conference, 2001, and the 6th ISNIE conference, 2002 as well as at seminars at the Universities of Aarhus and East Anglia. We thank the participants and in particular Graham Brownlow, Francesco Galassi, Tim Guinnane, Rob Heverly, Markus Lampe, Karl Gunnar Persson and Rich Sexton for helpful comments.
} 


\section{Introduction}

As is well known, the cooperative movement in Denmark was extremely successful, not just in terms of increasing production and quality, but also in terms of the number of cooperatives and their size, see Henriksen (1999) and O'Rourke (2002, 2007). Recent work has reaffirmed the crucial importance of the cooperatives for dairying (Henriksen et al 2011). Moreover, this development was already apparent from a far earlier date than most other countries, taking off already in the 1880s. In the late nineteenth century, Danish butter increased both its market share and price in the important English market. In doing so, it largely benefited the cost of another large supplier to that market, Ireland. As described in Ó Gráda (1977) and McCabe (1906), the growth in creameries and in particular cooperative creameries was slower in Ireland than in Denmark and, at least before 1914, their success was more modest. By 1906, Denmark, which possessed just half the land area of Ireland, had almost twice as many creameries, of which over 80 per cent were co-operatives as compared to just 44 per cent in Ireland.

Successful development of cooperation is critically dependent upon the homogeneity of economic interests among members. That is one reason why cooperatives tend to have a larger market share in products that are simple to grade like butter. But as Hansmann (2000, p. 140) puts it there is evidence that homogeneity among members 'along with other more personal dimensions can also be important' and that cooperatives emerged 'when the local farmers have shared unusual cultural homogeneity' ${ }^{2}$. O'Rourke (2007) takes this question a step further in his analysis of the failure of the Irish cooperatives. Not only is he interested in cultural homogeneity as such but also in the concept of social capital, particularly associated with La Porta et al (1997) whereby certain cultures promote more trust, which fosters cooperation and thus in turn aids macroeconomic performance. His focus is on the link between culture and trust, and it is here he finds the heterogeneity of Irish society to be a major cause of lack of trust, thus making cooperation difficult. We argue, however, that neither cultural homogeneity nor a trust promoting culture were sufficient conditions for the success of the cooperative movement in Denmark.

\footnotetext{
${ }^{2}$ Hansmann then goes on to mention people of Scandinavian descent in the United States as an example.
} 
By choosing to go beyond this focus on culture, we base our analysis within the framework offered by Williamson $(1998,2000)$ and the 'new institutional economics'. We reproduce in a simplified form his figure 1 here for illustrative purposes (Williamson 2000, figure 1). Within this framework, O'Rourke has in a sense focused on the first level and shown that it was lack of social capital which meant that Ireland failed to create working cooperatives.

Figure 1: Economics of Institutions

\begin{tabular}{|c|c|c|c|}
\hline $\begin{array}{l}\text { Embeddedness: } \\
\text { informal } \\
\text { institutions, } \\
\text { customs, traditions, } \\
\text { norms, religion }\end{array}$ & $\begin{array}{l}\text { Institutional } \\
\text { environment: formal } \\
\text { rules of the game-esp. } \\
\text { property (polity, } \\
\text { judiciary, bureaucracy) }\end{array}$ & $\begin{array}{l}\text { Governance: play of the } \\
\text { game-esp. contract } \\
\text { (aligning governance } \\
\text { structures with } \\
\text { transactions) }\end{array}$ & $\begin{array}{l}\text { Resource allocation } \\
\text { and employment } \\
\text { (prices and } \\
\text { quantities; } \\
\text { incentive alignment }\end{array}$ \\
\hline
\end{tabular}

A number of things lead us to look for more reasons for the success in Denmark than those attributed to the failure in Ireland. First, some have criticized the emphasis on necessarily rather intangible concepts like trust in an economic context, in particular Williamson (1993), who points out that it is simply a new name for information and enforcement, which are well understood in economics ${ }^{3}$. Second, Ahlerup et al (2009) have shown that the marginal effect of social capital decreases with institutional strength, and in fact vanishes when institutions are very strong. So if, as we believe, Danish institutions were of crucial importance to the success of the Danish dairy industry, then we cannot use the evidence presented by O'Rourke for Ireland to imply anything about the reasons for the success in Denmark, where it is the institutional setting that we must understand. Undoubtedly, the informal institutions had to be workable, but as the Williamson framework shows, this is not a sufficient condition for eventual success.

Thus, in terms of Williamson's model, before the fourth level where standard profit maximization is necessary for the working institution, there are two more levels which Denmark also had to get right: the 'formal rules of the game' and the 'play of the game'. We first discuss the former with a comparison to other countries, including of course Ireland, where it turns out

\footnotetext{
${ }^{3}$ Guinnane (2005) illustrates this point with some examples from the use of microcredit.
} 
there was a crucial legal distinction with Denmark. Then we turn to the latter which we are able to document with incredible detail through a unique primary source: the detailed minute books of a large sample of Danish cooperative creameries.

It used to be a popular belief in Denmark that the cooperatives preferred to be 'masters of their own house' without resort to the legal system at large. We demonstrate to the contrary that the Danish cooperatives frequently resorted to legal advice and the court system. The legal background (rules of the game) permitted the enforcement of contracts (play of the game) which allowed a successful cooperative movement to emerge, solving various incentive problems associated with cooperatives in general and the dairy industry in particular. These are analyzed in the following section.

\section{Incentive problems}

New technology can lead to such radical changes to the mode of production that new governance structures are required to deal with the resulting incentive problems. One such example is the steam driven continuous cream separator invented in 1878 and improved in the following few years. This invention had a revolutionary impact on the production of butter in Denmark. The majority of dairy cows belonged to small herds ${ }^{4}$ and because previous technology was not well suited to extracting cream from milk which had been transported by road, the majority of butter was produced in small quantities on the farms and crofts. Wholesalers preferred large homogeneous batches of butter as these fetched higher prices (see Rashid 1988). Thus, even if some of the farmers produced butter of high quality, they rarely obtained comparable prices for it. The continuous cream separator changed this by being able to extract cream from milk efficiently even where this milk had been transported some distance. Thus, by bringing together the milk from many small producers, the large batches of butter desired could be produced economically. However, the shift from local production where the owner of the milk transformed this into butter and received the rent thus created, to large scale manufacturing of butter from milk supplied from a large number of small and

\footnotetext{
${ }^{4}$ Talking in terms of herds rather than farms makes sense as some of the owners of cows were neither farmers nor smallholders, but teachers, priests, blacksmiths etc. The mean herd size was 6-10 cows.
} 
middle-sized herds, created new incentive problems. These arose because the new process required a separation between the supplier of raw milk and the producer of butter.

The minimum efficient scale for the new technology corresponded to the supply of milk from approximately 400 cows. $^{5}$ Building a creamery which made use of the new technology and procured its input from a large number of small and medium sized herds required a considerable investment in assets which were relatively specific. As the creamery had to be built first, the threat of hold-up was clearly real and anyone financing the building of a creamery would ideally want to secure the supply of sufficient milk for a period long enough to finance the capital. The solution that came to dominate in Denmark was to form a cooperative, whereby a group of herd owners collectively owned and financed the creamery, hired a manager and possibly bought raw milk from others.

Even with a cooperative, however, certain incentive problems remained. We concentrate on two: the risk of members exiting, and the incentive for suppliers to adulterate the milk before delivery to the creamery.

Free exit from the cooperative threatened the future viability of a creamery in three distinct ways. First, because of the returns to scale, exit could in theory increase average costs, lowering the return to remaining members. Second, as members were jointly liable for the existing debt, exit would increase the liability of those who remained. ${ }^{6}$ These two effects could potentially combine to lead to a wave of exits as decreased profits and increased liability made the outside options look more appealing, a wave which in the extreme would threaten the survival of the cooperative. The potential for such runs on a cooperative is identified and analyzed by Rey and Tirole (2000).

\footnotetext{
${ }^{5}$ Kyed (1910, Table 1) found working expenses almost 25 per cent higher for a small creamery compared to the largest ones. Even in 1903-04, almost 25 years after the first butter factories, data from 523 cooperative creameries confirm that the minimum efficient scale corresponded roughly to milk from 400 cows.

${ }^{6}$ Members were typically liable each in proportion to their number of cows or the amount of milk supplied over a given period. However, if one or more members could not meet their obligations, the remaining members took over their liability, again in proportion to cows or milk. Thus if only one member had any money, he would shoulder the whole liability.
} 
The third effect is more specific and relates to the collection and carting of the milk to the creamery. The vast majority of creameries organized this collectively by agreeing on the number and shape of collection routes. Where you were on the collection route mattered to the individual farmer for two reasons. It determined when your milk would be collected and hence when you had to start milking and it determined when you would get the skimmed milk returned to feed to your pigs and calves. Being the furthest away from the creamery was clearly not an attractive proposition and the design of the routes was the source of much debate and ruction in the cooperatives.

Besides the possibility of exit, the other major problem that faced cooperatives with many suppliers of milk was the risk of adulteration of the product. An agrarian economist, M.C. Pedersen, working in the mid 1880s at the infancy of the cooperative movement, referred to adulteration as the major threat to the creameries spontaneously mentioned to him by many dairy farmers (Pedersen, 1885 p. 47). Bøggild (1899) identifies three broad types of adulteration of the raw milk supplied to the creamery:

(a) the addition of something, such as water or skimmed milk, to the milk,

(b) the extraction of cream from the milk, either by skimming or by taking milk from the cans after the milk had settled,

(c) not milking the cows clean by getting the last drop from the udder. ${ }^{7}$

The consequence of all three forms of adulteration is that the amount of butter fat per pound of raw milk is reduced. The implication for the creamery of this depends on how the cooperative paid for the raw milk.

During the early period and certainly before 1887, a reliable technology to test the 'quality' of the raw milk in terms of how much milk it would take to produce a pound of butter was not available. The only option was then to pay members as well as suppliers according to the quantity they supplied, i.e. by weight. Typically a member would receive a fixed price for a

\footnotetext{
${ }^{7}$ A report in Mælkeritidende in 1901 (p. 789 - ) illustrates the consequence of not milking the cow clean. Dividing the amount milked from a cow into 17 equal subsamples, if all milk was as the first 17th, 156.4 pounds of milk would be required to produce one pound of butter, if as the middle 17th 21.5 pounds of milk is required and if as the last 17th, only 9.1 pound of milk would be required. The decrease in milk per pound of butter is particularly dramatic for the last fraction.
} 
pound of butter for each 28 pounds of milk supplied ${ }^{8}$ paid either fortnightly or monthly together with a share in the surplus determined by his share of the annual supply of raw milk. When paying for quantity in this manner, type (a) fraudulence not only led to a larger payment for the raw milk, but also a larger share of the surplus. In addition as the cost of producing milk was directly related to the quantity of milk processed rather than butter produced, it led to an increase in costs and consequently a smaller surplus. Other members were thus hit twice on the cost side as well as on their share of the (reduced) surplus. Types (b) and (c) only had a significant effect on the amount of butter produced, while the benefits to the fraudsters depended on what they did with the cream or milk. ${ }^{9}$ Intuitively, others were harmed most through (a) and one might therefore expect punishment for this to be harsher. ${ }^{10}$

The contracts drawn up by the cooperatives were thus of crucial importance insomuch as they could counteract the incentive problems described above through sanctions in the event of noncompliance. This they could only do if the contracts were enforceable, and it is here that the Danish legal environment played a crucial role.

\section{Rules of the game: Danish law and Danish cooperatives in an international context}

Legal origins do matter. According to La Porta et al (2008) there is a high correlation between the historical origin of a country's legal system and a broad range of its laws and regulations, as well as with economic outcomes. The main argument for this is that some countries, the more successful ones, offer more protection of outside investors be they shareholders or senior creditors (for example savings banks with a mortgage in land or real estate), than others.

\footnotetext{
${ }^{8}$ A competent dairyman with an unadulterated supply of milk should be able to produce a pound of butter using less than 28 pounds of milk, typically around 26 pounds. The price paid was also typically below the market price. This implied that when the creamery had paid for the raw milk, there would be some revenue left over to cover the cost of producing the butter. In addition, the waste products such as skimmed milk and buttermilk were sold back to the farmer. The implication was in most cases that there was a surplus to distribute.

${ }^{9}$ In most cases it was consumed at the farm (there are allegations of more fraud of type (b) during the strawberry season), but in a small number of cases butter is produced for sale.

${ }^{10}$ From the evidence presented below, it seem this might have been the case: $38 \%$ of cases where type (a) breach is explicitly noted involved severe penalties, while the same is only true for $28 \%$ of type (b).
} 
Legal traditions are usually categorized into two main groups: common law (originating in English law) and civil law (originating in Roman law). The former is usually considered to be rather more protective of outside investors than the latter and French civil law in particular. Other studies have found that common law is associated with less formalization of judicial procedures and thus greater judicial independence than civil law, and in turn better contract enforcement and greater security of property rights (La Porta et al. p.286). ${ }^{11}$

Within Continental Europe, however, the situation is rather more nuanced. German legal tradition has its basis in Roman law, but the German Commercial Code was written in 1897 after the unification of Germany. According to La Porta it 'shares many procedural characteristics with the French system but accommodates greater judicial law making.' As for Scandinavia, La Porta et al $(1998$, p. 1119) describes how the 'Scandinavian family is usually viewed as part of the civil law tradition, although its law is less derivative of Roman law than the French and the German families'. In the same work La Porta et al $(1998$, p. 1141) find that Scandinavia scores highest in a measure of the quality of law enforcement, higher even than common law countries. German law enforcement also scores quite high. This the authors explain by the role of professional bureaucrats, the military or civil servants in these two traditions. The score he calculates was based on measures of the efficiency of the judicial system, the rule of law, corruption, the risk of expropriation and the risk of contract repudiation by the government.

Ireland, as part of the United Kingdom, was firmly routed in the common law tradition and an obvious contrast with Denmark. Recent accounts have, however, usually failed to focus on the judicial differences between the two countries. One might wonder whether the Irish were simply unwilling to agree, monitor and enforce rules, and indeed Guinnane (1994) shows that this was the case for credit cooperatives. It was however also the law and not its use which made the difference, as highlighted over a century ago by McCabe (1906):

\footnotetext{
${ }^{11}$ La Porta et al admit, however, that there is a good deal of legislation in common law countries and a good deal of judicial interpretation in civil law countries.
} 
'The Danish dairying societies, recognizing that a regular supply of milk is a sine qua non of successful co-operative dairying, bind their members to send all their milk to the societies to which they belong under penalty of the payment of a heavy forfeit.* As such agreements have been declared non-enforceable at law in Ireland, the dairy associations are called upon to take stringent measures to protect the great majority of the members from injury at the hands of the few.'

* 'In Denmark the members of co-operative societies take no shares, unlimited liability and agreements to deal with no other parties being the rule. This, of course, gives the societies more solidarity than is possible under the Irish system, where everything is based on the farmer's interest as milk supplier rather than his obligations as a member of a society.'

(McCabe, 1906, p. 561-562)

McCabe's argument is that the contractual term is important in Denmark and unavailable in Ireland. The reason for the latter is that it is a form of restraint of trade and contract terms implying a restraint of trade are typically void and may even be prohibited in English law ${ }^{12}$ either because restraints are deemed to be against the public interest or because they are deemed unfair. An illustration of this is given by the case of McEllistrem v. Ballymacelligott cooperative $^{13}$, where it was found that a term tying the farmer to the creamery for an extended period was void. According to Clark (1982, p. 157), 'the House of Lords reasoned that while the respondents were entitled to protect their venture by ensuring stability, both of supply and in the lists of their customers the restraint went further than was necessary to ensure this'. Thus it was not up to the creameries to set the period of restraint of trade. According to Smith (1961, p. 115), the result of the McEllistrem v. Ballymacelligott cooperative decision was that 'Irish cooperatives, at all levels, work on the assumption that members are free to trade where they wish'.

An even more prominent example of the conflict between competition law, as it applied to trade restraints, and the operation of cooperatives, is found in the US before the signing of the Capper-Volstead Act in 1922, which explicitly legalized farmers' cooperatives. The US, naturally, shares most characteristics with the common law tradition. At the same time the legal practice

\footnotetext{
${ }^{12}$ If a contract term is void, it cannot be enforced, whereas if it is prohibited, it is illegal to include it or perform it.

${ }^{13}$ [1919] A.C. 548. This Irish case went to the House of Lords, which deemed an exclusive dealing agreement between a member and a cooperative dairy unreasonable and hence the contract void.
} 
guiding economic life varied between states, and cooperatives did manage to flourish, famously in the grain sector and the fruit sector.

Although the first American dairy cooperatives are reported in Connecticut during the first decade of the $19^{\text {th }}$ century (see for example Barnes and Ondeck 1997 p. 1, DiGuiseppe 2010 p. 1), it was not until after the Civil War that they really took off. High food prices combined with a decline in the workforce inspired more efforts in marketing and mechanization. Moreover, the introduction of the cream separator in 1879 prompted the collection of milk from remote farms to be collected, processed into and marketed as a uniform project. The subsequent decline in prices, including milk prices, in the 1870 s and 1880 s gave a further incentive to cooperate, namely, to create a counterforce against large buyers. ${ }^{14}$

The dairy industry spread from the North Atlantic, to the settlements of the East North Central and the West North Central ${ }^{15}$. Danker (1968, p. 21) highlights the immigration of Northern Europeans, particularly Scandinavians, 'who soon capitalized on their European experience with cooperatives by forming cooperatives in the US.' According to Schriver (2005 p. 4)) early cooperators 'drew upon cooperative traditions that immigrant dairy farmers had brought with them from Northern Europe.' Keillor (2000) puts a strong emphasis on the Scandinavian background of the early cooperators in Minnesota. The 'ethnic homogeneity' is said to have paved the way for close cooperation. Not surprisingly, these states provided a particularly favorable legislative environment, most famously in Wisconsin, where a law legalizing cooperatives was enacted already in 1887. It was eventually updated in 1911, and copied in many other states, laying the groundwork for the eventual passage of the federal CapperVolstead Act (Lawless 2002 p.3).

\footnotetext{
${ }^{14}$ Even if this motive is highly visible in European cooperative history, too, the US case is particularly interesting in that a number of the cooperatives established during the early $20^{\prime}$ th century were solely bargaining cooperatives, that bargained for a price between farmers and private distributers, mainly of liquid milk (Cropp and Graff 2001 p. 3). Fernández (2010) points out that the bargaining situation of the primary producers was particularly critical when their produce was either perishable, like liquid milk before refrigeration, or should be store in order to obtain the best price, like grain and young wine.

${ }^{15}$ See, for example, Dairy Economics Handbook No. 138, p. 5 USDA 1958
} 
On the federal level, however, it seems that cooperatives in the US were met with greater obstacles even compared to most other Common Law countries. ${ }^{16}$ The Sherman Antitrust Act of 1890 is the primary federal antitrust law and forbids 'every contract, combination in the form of trust or otherwise, or conspiracy in restraint of trade ...' Section 2 forbids 'monopolization, attempts to monopolize, and conspiracies to monopolize any part of commerce...'. Stiff fines and penalties are imposed for violations of the Sherman Act: three years in prison, high fines or the larger of twice the pecuniary loss to the victims or twice the pecuniary gain from the crime.

The Sherman Act does not contain an exemption for any specific industries and groups, although an amendment had been considered which would have exempted agricultural cooperatives. The development of cooperatives were thus hampered by an understandable fear among farmers that the Sherman Act could be applied to outlaw them. This fear was justified after a Supreme Court decision in 1908 (Loewe v. Lawlor), and farmers were indeed prosecuted in several state courts for price fixing under state law versions of the Sherman Act (Barnes and Ondeck 1997, p. 4). As Schriver (2005 p. 5) notes, even when leaders of associations were criminally prosecuted and found not guilty, 'the prosecutions were a disturbing element in the advancement of dairy cooperative associations ${ }^{\prime 17}$ and it was not until 1922 that the 'Magna Carta' of US cooperatives, the Capper-Volstead Act, was enacted.

Turning to the civil law tradition, the specific role of the legal system in relation to German credit cooperatives has been treated by Guinnane (2010). Cooperatives were under German Law faced with legal hurdles during the nineteenth century. In some German states their very existence was made difficult by limitations to the freedom of assembly. Cooperatives, according to Guinnane (2010, p. 1) could be forbidden, regulated, or overseen by the police. This was far from the rights existing in the Common Law area in the latter half of the nineteenth century. On the other hand, for historical reasons, German legislators bore no ill will against binding constraints of trade or vertical integration. Several examples from the mining and metal

\footnotetext{
${ }^{16}$ See, for example, the website of Fonterra Co-operative Group Ldt. on New Zealand and Goddard (2002) on Canada. Fernández (2010 p. 27) specifically mentions that Canadian wheat pools could force the members the supply their entire output to the cooperative.

${ }^{17}$ See, also Cropp and Graf (2001, p. 8) for a criticism of the Sherman Act applied on cooperatives
} 
industries testify to this and, moreover, members of the Danish speaking inhabitants of North Schleswig (included in Germany 1864-1920) emulated the dairy cooperatives from their Danish peers north of the national boarder already in 1886 , when their first cooperative creamery was established. This happened apparently without clashes with German law.

Moreover, unlike in the common law countries there was at an early date legislation in the German states dealing explicitly with cooperatives. The Prussian law of 1867 was to be the basis of the later Reich cooperative act of 1889 . The 1867 law allowed registered cooperatives the status of legal entities, that is they could borrow and lend, buy and sell, and sue and be sued. The 1889 law required external auditing and allowed cooperatives to be members of each other. It also introduced the option of limited liability for cooperative members.

Generally, then, cooperatives did not face a wholly unfavorable operating environment in Germany: the German legal system acknowledged the existence of cooperatives from an early date, unlike both common law countries and even Denmark herse If $^{18}$. It seems, however, that their priorities were somewhat different. A keen observer of Danish and German agriculture, Brinkman (1908), emphasized that the first and foremost aim of any rural association in nineteenth century Germany was to relieve the credit constraint (Kreditnot) of German farmers. Only after this had been achieved could the cooperatives spread their activities to other areas such as the buying of farm supplies and the processing and marketing of farm products. Furthermore, Brinkman stressed that this point of departure was different from that of the Danish dairy industry which, apparently, did not see lack of credit as an insurmountable obstacle to the formation of processing and marketing cooperatives.

An obvious comparison to make with Denmark is the Netherlands. According to Fernandez (2010, Table 2, p. 37) the Netherlands came only second to Denmark in 1908 when looking at the percentage of total butter production produced in cooperatives. Moreover, the dairy sector in the Netherlands was export oriented early on, a factor that seems to have favored the development of cooperatives.

\footnotetext{
${ }^{18}$ Although elsewhere in Scandinavia, Sweden enacted a cooperative law in 1895 (Lag om ekonomiske Foreninger). Norway, like Denmark, had no law on cooperatives until well into the twentieth century.
} 
In the late 19th century, however, the beginning of cooperation was not quite as auspicious as that in the Denmark, and apparently the legal framework was again of importance. Agricultural cooperation, if not in name, began early in the nineteenth century, as in many other European countries, in mutual insurance, and from the 1860 s and 1870 s also in local associations that bought fertilizers, seeds, animal feed and breeding stock for their members. Associations of this sort were usually founded under the Dutch law of the freedom of association of 1855 or they were registered as limited societies.

In 1876 the Netherlands enacted a cooperative law more or less copied from the Prussian law of 1867 , but the immediate effect of this was unimpressive. Rommes (2008, pp. 6-8) finds that the main explanation for the few cooperatives registered under the law was the unlimited liability of the members. In an environment of restricted lending capital and poorly developed banking, limited liability was seen as a more effective way of attracting funds. It may be telling that the most successful early cooperatives were smaller and less well equipped than the limited liability cooperatives. One would have thought that the Dutch countryside was ripe for the development of Raiffeisen credit cooperatives given the inspiration from Germany, but the real take-off of these banks (Boerinleenbanken) was still rather late, coming not until the first decades of the twentieth century (Rommes, 2008 p. 10).

Turning at last to Denmark, an exceptional feature seems to have been that the legal system positively encouraged the cooperative movement, unlike the countries described above. A number of factors played a role in providing this favorable environment.

In contrast to the situation in some other continental European countries under the Civil Code system, the Danes, according to the Constitution of 1849, were guaranteed freedom of assembly $^{19}$ and the freedom to form associations. Moreover, freedom to contract in regard to the law of property (aftalefrihed i formueretlige forhold) was a pillar of Danish law. Thus, the courts would tend to accept even the most stringent of statutes written by a cooperative. This could be relevant in cases where members wanted to exit (Hørlyck 1999 pp. 117-118).

\footnotetext{
${ }^{19}$ With the possible exception of the intolerance towards the first demonstrations arranged by the labor movement, notably in 1872.
} 
Additionally, cooperatives were regulated by the Business law, the Competition law, and the Sale of Goods Act. The first two laws presented no obstacles to the cooperatives, and the latter was supportive and for example relevant in cases where they had been supplied adulterated milk.

Despite this, there was in fact no cooperative law by name in Denmark until as late as 1999. In its place a supplementary/complementary case law (udfyldende retsregler) developed over time to form the basis of court decisions. Although we find that the courts weighed the concerns for all parties involved in individual lawsuits they often referred to precedent created by earlier cases. This in itself was of course not so very different from the situation under other legal systems. What was different was the extent to which the Danish legal system seems to have treated the cooperatives as separate legal entities, thus giving them more options under the law than in most other countries (Hørlyck, 2000).

Since there was no formal law incorporating the cooperatives, the Danish constitution's freedom to form associations enabled a group of people to write and enforce their own by-laws or statutes. ${ }^{20}$ The governance structure of the Danish cooperatives was defined by these statutes which all members signed up to, and which had the features of a contract between each member and the cooperative. ${ }^{21}$ As already mentioned, the individual cooperative had considerable freedom to design its own statutes. They were similar in structure and content and generally committed each signatory member to (a) supply all his milk not used in his own household to the cooperative; (b) for a given period of time, typically the length of the loan period, and (c) without adulteration; (d) observe certain specified standards of cleanliness; (e) observe certain standards of feeding the cows; (f) share in the profits according to a specific formula, typically the amount of milk delivered in the year; but also (g) share in any losses which might arise and any outstanding debt, both according to a formula.

\footnotetext{
${ }^{20}$ In the following we will refer to the (by)laws of a specific cooperative as its statutes to avoid confusion with the non-existent national law of cooperatives.

${ }^{21}$ Noticeably, the Danish High Court refers to the laws and statutes as a contract between members.
} 
In many cases fines for breach of (a) - (e) were specified explicitly. The courts interpreted the statutes as contractual terms $\mathrm{s}^{22}$ and would in almost all cases enforce them, the sole exception being a term which precluded members from appealing decisions of the general meeting to the courts where the appeal concerned the application of the statutes. ${ }^{23} \mathrm{~A}$ cooperative in Denmark is then best seen as a nexus of long-term contracts, where the terms of the contract are given in its statutes (see the overview in Cook, Chaddad and Iliopoulus 2004). Along with Masten (2000) we define a contract as a formal, legal commitment to which each party gives definite approval and to which a particular body of law applies.

A contract which committed a member to supply all his milk to the same creamery for a well defined, but possibly long, period of time (usually 10, but sometimes 7 years) was enforceable by Danish courts, in contrast to the situation in Ireland, for example. Legally, a cooperative could prevent exit for any length of time it chose to specify in its statutes. It was, however, important that the statutes specified a period. If nothing was specifically mentioned then the court would apply some reasonable criteria for the period of notice. ${ }^{24}$ If a creamery had no rule at all against untimely exit, its legal position would be weak (Dyrbye 1954, pp. 46-47).

When it comes to breach of contract for which the parties can include damages in the contract, one can distinguish between liquidated damages and penalties. The latter is enforceable in Danish law ${ }^{25}$. Cooperatives in Ireland, for example, would only have been able to look to the

\footnotetext{
${ }^{22}$ See e.g. the 1895 High Court case A.S. Nr. 20/1895: Farmer Chr. Bertelsen vs. Sønder Farup Andelsmejeri.

${ }^{23}$ See the 1895 High Court case A.S. Nr. 948/1895: Haastrup Fællesmejeri vs. J. Nielsen. One could interpret the right to appeal as similar to a judicial review. Willamson remarks, quoting Galanter (1981) that this kind of attempt to avoid the court system can be explained by the belief of the participants that they can devise a more satisfactory solution than the professionals who would have to apply a general rule (2005).

${ }^{24}$ This is evident from the Appeal Court case no. 700/1899 between the board of Svindinge Andelsmejeri and Mr. C. Christoffersen. According to the court: 'A cooperatist or so called shareholder in a cooperative creamery has, irrespective of whether the creamery statutes offers no rights to exit, the right, offering a reasonable notice, to bring his duty to supply the creamery to an end, as such a form of exit must be consistent with the case and with normal law and the laws of the creamery does not forbid it.' The decision also makes clear that if nothing else is written, 5 months seems a reasonable period of notice.

${ }^{25}$ This is not the case in English law. Although the distinction between a penalty and liquidated damages is not always clear, the English view is that 'it is essential that the sum payable should really be intended as compensation, and not as a threat or penalty, held over the other party's head to compel performance' (Atiyah, 1995, 434-435)
} 
former. One important issue with respect to the size of the liquidated damages is the extent to which they can include a consequential loss. This again turns on how remote and foreseeable the cost of the breach is to the defendant and may be considerably lower than the expected losses. For Denmark, on the other hand, a High Court case illustrated that penalty clauses were enforceable. ${ }^{26}$ Indeed, the court appears to argue that the size of the penalty is of no concern once it is established that it is a penalty. This was relevant in all cases of breach of contract (for example early exit or adulteration).

In fact, judges often showed remarkable understanding of the incentive problems facing the cooperatives. Mælkeritidende, (the leading Danish dairy journal) reports on an arbitration court case from 1909 regarding a delivery stop by a large landowner, referred to as I.T., who as a member of the cooperative had committed himself to supply milk from 40 cows to a creamery which in total received milk from 484 cows. Loosing almost 10 per cent of the milk was serious for a creamery of this size and it is not surprising that the cooperative attempted to force I.T. to resume supply and also to pay compensation. ${ }^{27}$ Advocate of the High Court Fritz Bülow was the arbitrator and found that although the statutes did not expressly forbid somebody from withdrawing it was clear from the statutes that this was the intention. Hence he found that I.T. was in breach and followed the requested restitution, namely performance. The argument for requiring performance under the agreement was that determining the monetary loss was very difficult. In particular,

'if a member ceases to deliver his milk to the creamery, the effect may be negligible, ... especially if the member is small, however if more members follow suit, at some point in time the effect on the cooperative may become fatal...and the damage is, of course, not caused by the last member to leave the creamery for which reason he cannot be held responsible for the loss. It will probably be too late to look to the members who left early since the legal question in their cases may have been settled long before.' Mælkeritidende (1909, p. 540)

\footnotetext{
${ }^{26}$ See A.S. Nr. 14/1895: F. Frederiksen vs. Andelsmejeriet Fuglekilde.

${ }^{27}$ This case also gives us an insight into the possibility of opportunistic behavior by a large member. What prompted the refusal to supply in this case was the announcement of a change in the statutes of the cooperative. An adoption of a one-member-one-vote principle would adversely affect members with large herds.
} 
The legal system and the court were thus generally supportive of the cooperatives to the point of understanding what it was they were trying to achieve. ${ }^{28} \mathrm{~A}$ cooperative could delay exit with reference to a specific rule in their statutes but never for more than 5 and 2 years respectively. As demonstrated above, the period for which a member or supplier could be tied was of course even shorter in Ireland.

The establishment of the concept of limited liability is often seen as crucial to historical success, but in fact the Danes held on to the principle of unlimited liability joint and several ${ }^{29}$ (ubegrænset ansvar med solidarisk hæftelse) until the latter half of the twentieth century. ${ }^{30}$ One reason why the Danes kept the principle of unlimited liability for so long was probably due to their more favorable financial position. This in turn owed much to the early transition from tenant to owner-occupied farming in Denmark. Consequently, at least the owners of large and middle-sized farms had land to mortgage, given the opportunity.

Compared to other countries, the legal framework in Denmark (despite the lack of a formal cooperative law) was well suited for the purpose of establishing dairy cooperatives during the late nineteenth and early twentieth century. The combination of both civil and common law features was of great importance: the Danish cooperatives were able to enjoy the rights, freedom and flexibility of the common law system while at the same time benefitting from a legal environment that did not find their activity to be in conflict with free competition. Institutions in the second level of Williamson's model were thus supportive of the success of the Danish cooperatives - but this was still not sufficient. The play of the game, or how the system was used and enforced, was also necessary. The following section demonstrates that the Danish cooperatives exploited the legal avenues available by writing contracts which were then rigorously monitored and enforced.

\footnotetext{
${ }^{28}$ In comparison Swiss and German cooperative law allowed members a year and three months respectively to withdraw from their contracts with the association. According to Hørlyck (2000, p.13) the normal praxis in Sweden, if nothing else is stated, is at the end an accounting period.

${ }^{29}$ That is an outside creditor should, first, lay a claim on the assets of the creamery, buildings, machinery, tools etc., before laying claim to the assets of any of the individual members.

${ }^{30}$ Although today cooperatives usually use limited liability (andelsselskab med begrænset ansvar, a.m.b.a).
} 


\section{Play of the game: Contracts, monitoring and enforcement}

\section{The Sources}

Our documentation of the use of the legal system by Danish cooperatives presented below relies on evidence from a number of sources. We have extracted information from the books of minutes of the general meeting and the board meetings of 215 cooperative creameries, roughly one in five of the 1100 cooperative creameries that existed around 1900. Although the level of detail in these hand-written records varies considerably from creamery to creamery, they generally give us detailed information about the sort of contracts used, as well as cases of breach, enforcement or renegotiation of these contracts.

The books of minutes were important documents for the cooperatives, which may explain why so many have survived until this day. They are the evidence not only to posterity but also to contemporaries of how non-compliance with the statutes was monitored and how the appropriate sanctions were imposed upon fraudulent members. In the vast majority of cases the names of these members are given in the minutes as well. They thus served as the collective memory of the cooperatives and made for the shaping of future behavior by the members. They served as evidence of collectively binding decisions in court cases and thus complemented the statutes.

Most of the cooperatives in our sample, 138 of 215, were established during the latter half of the 1880s, a period of strong growth. Where possible, we follow the records from these creameries up to World War I. In some cases some of the books of minutes have been lost, but for 160 creameries we have the books for the whole period from foundation until 1915 . For a further 25 we have the books from the foundation, but some later years are missing. From 1888 onwards, we have the book of minutes from more than $85 \%$ of the creameries in our sample who had started production.

In addition to the archival material on each creamery, we also make use of another dataset: Mejeri-Driftsstatistikken (MDS). This annual national survey of creameries was first published in 1898 and contains accounting results from the previous year. It is based on voluntary reports from the participants and it contains information about the financial and technical performance of the cooperatives. At least 140 of the 215 creameries in our sample are represented at least 
once in MDS between 1897 and 1904. Finally we have made use of the trade press and court transcripts where available.

We cannot guarantee that our sample is representative. There is some overlap between our sample of minute books and MDS. 98 of the creameries in our sample are represented among the 523 creameries who returned accounts to MDS for the period November 1903 - November 1904. Comparing the mean and variance for the 98 included with the remaining 424 creameries, we find that the means of year of formation, raw milk processed, and butter produced do not differ significantly. The variances are only significantly different for the year of formation, where the variance is greater among the creameries not in the sample. This offers at least some comfort, but it should be kept in mind that those creameries where the books of minutes have been kept are not necessarily the ones that were active and open minded enough to supply statistical material to the annual national survey.

\section{The danger of exit}

As explained above, building a new creamery or taking over an existing one required capital which in almost all cases had to be borrowed. The viability of a creamery rested on its ability to obtain sufficient quantities of milk for a long enough period to pay back the necessary loans.

The cooperatives attempted to secure this through their statutes which tied members to supply all their milk to the creamery for the whole of the loan period, typically 10 years. We have complete records of the statutes for 49 of the creameries in our sample. Exit was either not allowed or required the permission of the board or a general meeting. Where the statutes allowed exit, these typically specified the costs. Of these, 19 explicitly prohibit exit within the loan period and 28 allow exit in return for payment of share of debt and/or the forfeit of all or part of the share of assets. A payment per cow in compensation is only mentioned in two cases. Two creameries are very vague about exit.

In case of untimely exit, a member committed himself to pay in his part of the gross debt and forfeit his share (Hørlyck 2000, p. 117). We observe a large number of different rules ${ }^{31}$, but they

\footnotetext{
${ }^{31}$ Here are a few examples: $\S 7$ from the revised (1887) statutes of Fuglebølle-Longelse Andelsmejeri, 1887 states that 'Exit from the creamery can occur after 15 years, measured from 1 . November 1887. If the exit at that date becomes so commonplace that it becomes difficult for the remaining members to run the creamery with a surplus at least comparable with what could have been achieved by supplying a private creamery, and hence it becomes
} 
all share the following: exit may be illegal, and if legal, is costly. The cost of exit almost always included the payment of the exiting member's part in any remaining debt and the loss of his share in the assets of the cooperative, and frequently an additional monetary compensation. At least part of the costs of exit and in particular the payment of the debt and the forfeit of the assets are almost certainly a penalty rather than a measure of the damages caused by the exit, a conclusion reached by a court in a fraud case. ${ }^{32}$ However, since Danish law allows penalty clauses in contracts, the court also enforced this perceived penalty.

Turning to actual cases of exits (either requested or due to refusal to supply), these are recorded in 118 creameries out of the 215 in our sample. These cases exclude those where members exit legally at the end of a loan period. A total of 257 incidences of exit of one or more members were identified. The cases may concern an individual or a group of individuals and the number of members included in a specific case in the sample varies from 1 to 112 . The level of detail recorded for each of these cases also varies considerably, partly we suspect because in some cases the laws were so precisely written that they were simply implemented as a matter of routine.

Apart from two cases which are hard to classify, ${ }^{33}$ the remaining cases fall into one of three categories. The first and most numerous consists of those member(s) who requested permission to leave the creamery and where the request was granted. There are a total of 142 such cases, corresponding to $55 \%$ of all cases. The second consists of those who made a similar request but were rejected, making up 50 (19\%) of the cases. In many, but not all of these cases, exit was either prevented or at least postponed. The third consists of illegal exits, where

necessary to liquidate the creamery, then any surplus or loss must be divided by those men who were members at the 31 . October 1902 in relation to the value of the milk each have delivered to the creamery during the five years prior to the sale of the creamer.' \$10 of the statutes from Lendemarke Andelsmejeri 1892 states that 'No member of the cooperative can exit the creamery without the permission of the general meeting, excepting members who sell or transfer their property to another who does not need the approval of the general meeting to enter the cooperative and who enters in his stead. Members who exit obviously have no claim on the assets of the creamery. ...' $\$ 23$ of the statutes from Staalbæk Andelsmejeri, 1900 states that '... if a member wishes to leave, he must pay his part of the debt and up to $10 \mathrm{kr}$. pr cow.'

${ }^{32}$ See A.S. Nr. 14/1895: F. Frederiksen vs. Andelsmejeriet Fuglekilde.

${ }^{33}$ In one case it is unclear whether the farmer in question was forced to move to another creamery. The other case concerns a speculative request to exit. 
members breached the statute on the supply of milk either by refusing to supply, by stopping supply, or by selling (part of) their milk elsewhere. These make up $63(25 \%)$ of the observed cases and mostly lead to permanent exit.

Since exit during the loan period is more costly than at the end of the loan period, members must have had strong reasons for wanting to exit early. In 107 of the cases, a reason for either the request or the illegal exit is offered. Table 1, where the illegal exits and the rejected requests have been merged, summarizes the information about the reason for exit.

Table 1: Reason for exit

\begin{tabular}{|l|r|r|r|}
\hline Reasons offered & Accept & Reject/illegal & Total \\
\hline Transport and/or New creamery & 35 & 21 & 56 \\
\hline Endogenous Ownership Change & 7 & 13 & 20 \\
\hline Exogenous Ownership Change & 14 & 2 & 16 \\
\hline Other & 10 & 5 & 15 \\
\hline Total & 68 & 41 & 107 \\
\hline
\end{tabular}

Perhaps the most striking feature is the role played by arguments over transport problems, although given that transport costs accounted for $25-30 \%$ of the running costs of the creamery this is not surprising. Disputes were often associated with the formation of a new, more conveniently located, creamery. Some peripheral members had to deliver their milk directly to the creamery in return for compensation or had to deliver the milk to a nearby road, or simply had to start milking very early. A new creamery in the neighborhood which could pick up the milk at the farm and at a more convenient time would then be an attractive alternative. This argument is made in more than half of the cases (53\%) and is successful in two thirds of these. Such members rarely represent a great loss to the creamery since they contribute significantly to transportation costs, nor is their exit likely to lead to further exits. ${ }^{34}$ Still, in one third of the cases, the request is rejected, typically because of the problems which the exit would cause for the collection routes.

\footnotetext{
${ }^{34}$ Occasionally the transport related exit is by a group of members located at the periphery of the creamery. On occasions, such as Møns 1888, Bodilsker 1889, Pederstrup 1889, Hallelev 1891, and Fjenneslev 1912, this leads to negotiation between the two boards about the terms of the transfer. These terms could be that the receiving cooperative collectively paid the exit fee, if any, to the old cooperative.
} 
A third of the cases in table 1 relate to the transfer of the ownership of the herd. They have been divided into those where the decision to transfer ownership was taken by the member through sale of the property, referred to as endogenous, and those where the transfer of ownership was exogenous because the member was a tenant, because the herd came with the job such as teachers and priests, or because the owner died. In the endogenous cases, only a third of the cases are accepted whereas the vast majority of exogenous cases are accepted. As the statutes typically allow the transfer of membership upon the sale of the property and as these are an isolated and relatively rare occurrence, one might have expected a higher degree of acceptances. However, it may be that a new owner is less credit worthy and hence the liability of others would have been increased by the sale of the property.

It is notable that there are very few cases where dairy farmers breached the statutes by selling their produce outside a creamery, only 3 out of 59 illegal exits relate to this. This type of 'exit' is given a prominent place in McCabe (1906). It may be that the incidence is understated, but in reality, such a breach is not relevant for all but those relatively few farmers who are located close to market towns. We find a few cases of exit as a protest against a change in the statutes or a reaction to a perceived wrong. ${ }^{35}$ Finally, the threat of exit was used proactively in a few cases in order to influence the decision of the creamery. A letter of September 1890 from a large dairy farmer to the board of a newly started cooperative is illustrative of the latter:

'By checking the fat content of my milk and by comparing it to that of other cooperative members I have become aware of the fact that the fat content of the milk supplied from many of the members is so low that it can only be explained by adulteration or by other kind of inadmissible conduct. I assume that the esteemed board will act vigorously upon this information now that I have called its attention to it so that it will not be necessary for me to carry the matter any further.' 36

In this case, as possibly in many others, the cooperative board took action in order to make a large member stay.

\footnotetext{
${ }^{35}$ In one High Court case, A.S. Nr. 20/1895: Farmer Chr. Bertelsen vs. Sønder Farup Andelsmejeri. a member had stopped supplying as a protest against changes to the collection routes. The court found that the dispute rested on a misunderstanding and that, as there had been 'no meeting of minds' there was no contract.

${ }^{36}$ Minutes from Stokkemarke Andelsmejeri, Lolland Falster, 17. September 1890.
} 
Table $2^{37}$ gives exits in relation to the number of years since the founding of a creamery. Exits were clearly more common in the early years of membership of creameries - particularly in the first ten years, and even more so in the first five years. This seems evidence of a learning effect where members observe how others have been treated in the past.

Table 2: Timing of exits

\begin{tabular}{|l|l|l|l|}
\hline From start & Accepted & Rejected & Illegal \\
\hline $0-4$ & 40 & 18 & 18 \\
\hline $5-9$ & 25 & 6 & 13 \\
\hline $10-14$ & 25 & 8 & 9 \\
\hline $15-19$ & 23 & 9 & 6 \\
\hline $20-24$ & 21 & 7 & 11 \\
\hline $25-29$ & 8 & 1 & 6 \\
\hline Total & 146 & 49 & 59 \\
\hline
\end{tabular}

Exit was certainly costly. We have information about potential monetary sanctions in 185 cases. In only 46 of these is exit costless. Interestingly, creameries where exit at least for some is costless also have relatively more requests for exit. Thus the 37 creameries where at least one case of exit was explicitly costless had on average 2.78 requested or actual exits, much higher than the average for the whole sample (1.18). The remaining 139 involved some form of compensation. Table 3 summarizes the information on damages.

Table 3: Damages in case of exit

\begin{tabular}{|l|r|r|r|r|}
\hline & Total & Accepted & Rejected & Illegal \\
\hline Explicitly costless & 46 & 41 & 0 & 5 \\
\hline Damages & 139 & 99 & 6 & 33 \\
\hline Exit fee/damages & 69 & 42 & 1 & 26 \\
\hline Pay part of debt & 32 & 22 & 3 & 7 \\
\hline Explicit loss of share & 63 & 54 & 2 & 6 \\
\hline Coachman compensated & 10 & 7 & 1 & 2 \\
\hline No information & 72 & 6 & 44 & 21 \\
\hline
\end{tabular}

Given that only a few of the statutes we have from the creameries in our sample include an exit fee or damages, it is interesting to see that this is the most popular form of compensation. The actual size of the exit fee varies considerably from an almost symbolic amount to, in one case

\footnotetext{
${ }^{37}$ The last five year period is misleading because there is a relatively small number of creameries where we have 30 years of observations.
} 
$50 \mathrm{kr}$. per cow, and in another, a total of $500 \mathrm{kr}^{38}$ Notice that there are cases where the coachmen collecting the milk are explicitly compensated. Finally, there are some rejected exits where exit nonetheless happens and hence compensation is due.

\section{The risk of adulteration}

The creameries gradually first introduced spot-checks of the quality of the milk and then moved to payment for the quality of the milk. Once they had converted fully to pay for quality, the concern about fraud was much reduced, since the fraudster would simply be paid less for his milk. Nonetheless, introduction of payment for quality was slow and not completed until well after $1905^{39}$.

From our sample of 215 creameries, 102 have at least one case of fraud recorded and we find a total of 275 cases of fraud. As the creameries have different start dates and as we do not always have the books of minutes for the start date until 1915, we have in figure 2 divided the number of cases in a given year by the number of creameries for which we had a minute book for that year.

\footnotetext{
${ }^{38}$ To put this in perspective, the value of a Danish milk cow listed in UK trade statistics was between around 150$300 \mathrm{kr}$. in the $1880 \mathrm{~s}$ and $1890 \mathrm{~s}$.

${ }^{39}$ Henriksen and Hviid (2004) demonstrate how adoption took place and its role in the success of the cooperative creameries.
} 
Figure 2: Fraction of creameries with recorded fraud cases 1887-1915

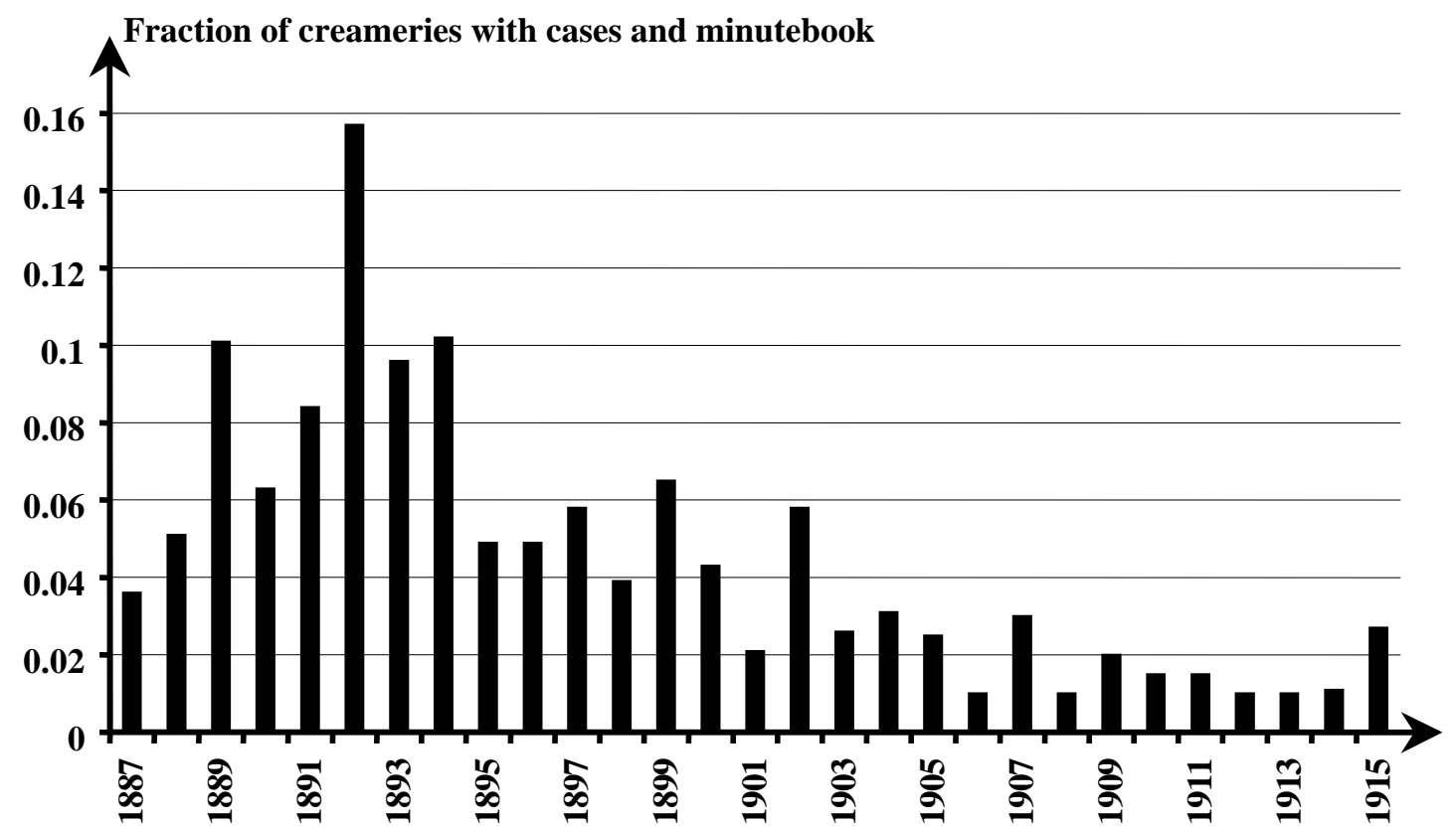

We see that most of the detected fraud takes place in the early years, certainly before 1902 and really centered around the period 1888 - 1894. This suggests either that suppliers became more honest over time, that the cooperatives became less successful in detecting fraud, or that this type of fraud simply became less relevant as the creameries all switched to paying according to quality. Given the delay in the full implementation of payment according to quality and given the increasing economic gain from cooperation to the individual our evidence certainly points to a change in behavior over time.

The success of statutes in deterring fraud would depend on the sanctions available in case of breach. We can think of three types of sanctions: (a) expected damages, (b) penalties and (c) termination of the 'contract', i.e. expulsion. The sanctions in the statutes have been recorded for 88 of the creameries in our sample. Of these $45 \%$ include all three elements, damages, penalties and exclusion. A full $80 \%$ allow for exclusion. Only one provides no information about sanctions.

The minutes are often imprecise in breaking down the total monetary amount to be paid in penalties and damages and rarely record the exact method for calculating the compensation. Penalties are mentioned in $51 \%$ of the cases while damages are mentioned in $45 \%$ of the cases. 
One thing that can be observed in most cases is the size of the monetary amount to be paid, which was generally high. We find 70 cases where the member was excluded, the fine together with damages exceeded $500 \mathrm{kr}$., or both of these. To some people such a penalty was likely ruinous.

Of the 275 cases of fraud 59 led to exclusion and exclusion was used as a punishment in 42 of the creameries. Such highly visible actions may have had a disproportionate effect on future behavior and may even have had preventative effects beyond the creamery itself, as the density of creameries were high in parts of the country, allowing information and rumors to spread. ${ }^{40}$ From the behavior regarding exclusion, we note from our sample that the board and the general assembly of members occasionally used some discretion in this serious matter. Such behavior could undermine the credibility of the sanctions, but may help explain the often very hefty fines.

Looking specifically at exclusion as a possible sanction, Danish legal usage took the same view as the cooperative laws in Sweden, Switzerland and Germany, that exclusion was justified in case of a 'substantial breach of contract', but not by an ordinary conflict of interest between the member and the cooperative. Also, exclusion of a member had to be sanctioned by the general meeting if not explicitly delegated to others, for instance to the board. The legal status of the excluded member, in principle, was the same as applied in the case of illegal exit (Dyrbye 1954, pp. 52-53, Hørlyck 2000, p. 126).

We rarely see cases of lenient treatment. A record from Funen in 1888 tells us that the member in question is let off with a caution 'because he is a poor man with many children'. But this is the exception. Cooperatives showed their social compassion in other ways, for instance, by giving poor people a privileged right to buy milk. The norm appears to be that if you have signed the rules, you abide by them or face the consequences.

\footnotetext{
${ }^{40}$ In one creamery, rumours like that leads to the board initially refusing to admit a farmer as a member. In at least one instance, a case was mentioned in the local newspaper.
} 
Table 4: The use of outside enforcement

\begin{tabular}{|l|c|c|c|}
\hline & observations & $\begin{array}{c}\text { Of which } \\
\text { confess guilt }\end{array}$ & $\begin{array}{c}\text { Of which } \\
\text { deny guilt }\end{array}$ \\
\hline Use of external body & 66 & 12 & 36 \\
\hline Threat & 25 & 4 & 5 \\
\hline Not mentioned & 161 & 55 & 22 \\
\hline No information & 23 & 2 & 4 \\
\hline Total & 275 & 73 & 67 \\
\hline
\end{tabular}

This is equally true when it comes to the statutes on fraud. Table 4 summarizes the information about outside involvement. In a small number of cases, 23 , the description of the case is so brief that we have no useful information. For a further 161 cases, the description is more substantial and no mention of outsiders such as lawyers, the police or courts are made. This naturally does not imply that the possibility was not mentioned to those involved.

What is interesting is that in a third of the cases, either an explicit threat is used, or they consult a lawyer, the police or take the case to court, in the extreme all the way to the High Court. Between 1895 where the first case appeared and up to 1915, 27 cases involving cooperatives got as far as the High Court or one of the two Country Courts in Denmark, the vast majority of cases being dealt with in the local lower courts.

For the period up to 1901, altogether no less that eight cases concerning cooperative creameries reached the High Court. Several of these concern interpretation of the laws and point to the importance of careful drafting. The majority of cases are about exclusions following adulteration. We are left with the distinct impression that in the real world the parties to the contract were able and willing to seek enforcement through the Courts if necessary. From the law records we find that Danish court fees were modest. Thus it would appear that access to justice was ready and inexpensive, suggesting that the transaction costs of using contracts were also relatively modest.

It may seem remarkable that there are so few reported cases of fraud. However, with a clear set of rules which are cheaply and willingly imposed by the courts, potential wrongdoers would have a fairly clear idea of the consequences if they were caught. That members were so willing 
to impose these strict statutes may be cultural, but is more likely related to the fact that fraud affected both the short-term results of the creamery and their long-term survival. As members had not only potentially unlimited liability and also invested in their herd, they may have been unwilling to be forgiving. A report from the Department of Agriculture and Technical Instruction for Ireland, 1903, contains the following supportive quote:

'The most interesting feature in every form of co-operation in Denmark is the extraordinary fidelity universally observed towards their own institutions by the people who participate in them. A member of a Danish Co-operative Society, deliberately violating the rules, would have certainly a very uncomfortable time of it in his district. Every one feels that the creamery or the slaughtery has been organised to develop the people's industry, and that with its success or failure the welfare of the people must stand or fall, and it is really astonishing the extremely few cases in which expulsion of members took place because of fraud perpetrated upon their Society. In this way co-operation has materially assisted in the development of Danish character.'

Report on Co-operative agriculture and Rural Conditions in Denmark, Department of Agriculture and Technical Instruction for Ireland, 1903, bulletin no. 7, p. 78-79.

Finally, turning to another kind of monitoring problem one might have believed that the position of the manager as a hired employee would invite a principle agent problem in the cooperatives. The notice on entering the job as manager was often brief, down to three months during the first years, and in 21 cases the dairy manager had to find security from 500 to 3000 kroner, the latter officially in case he was responsible for a machine breakdown. This fear hardly seemed warranted, however. Only 17 cases of fraud by managers in all our 215 dairies over all the period are recorded in the minutes. Most of these were 'small' transgressions like using more milk or cream for his own household than according to contract. Other cases were irregularities in the accounts. The modest frequency and size confirms the observation by Hansman (2000, p. 135): 'Boards scrutinize managerial performance closely and not uncommonly replace managers who are performing well.' Another good reason for the low frequency of offense by the hired managers was no doubt their job situation: for every job there was a two digit number of applicants. 


\section{Conclusion}

In a seminal article from 1951, Kindleberger pointed to the social cohesion in the Danish countryside which enabled farmers to create the necessary institutions. That may well be true as far as the establishment of cooperatives go. They did not emerge and thrive in a legal void, however, dependent only on informal trust. Instead they utilized the freedom to write their own statutes, which they subsequently monitored and enforced. Danish contract law assisted them in this by enforcing contracts, which were economically meaningful, but which might not have been available in other jurisdictions such as Ireland. In summary, it was Danish contract law, and not only the peace-loving homogeneous nature of the Danes, which allowed the cooperatives to thrive.

\section{References}

Ahlerup, P., O. Olsson, and D. Yanagizawa, 2009, 'Social capital vs. institutions in the growth process', European Journal of Political Economy 25:1, 1-14

Atiyah, P.S. 1995, An introduction to the Law of Contract, Clarendon Press, Oxford.

Barnes, Donald M. and Christopher E. Ondeck, 1997, The Capper-Volstead Act: Opportunity Today and Tomorrow. http://www.uwcc.wisc.edu/info/capper.html

Brinkmann, Theodor, 1908, Die dänische Landwirtschaft. Jena: Gustav Fischer Verlag.

Bøggild, B. 1899, Kortfattet Mælkerilære for Elever i Landbrugsskoler. Enst Bojesen, København. Bøggild, B. 1916, Mælkeribruget i Danmark. 4. udg. Gyldendal og Nordisk Forlag. København.

Clark, R., 1982, Contract, Irish Law Texts, Sweet \& Maxwell, London

Cropp, Bob and Truman Graf, 2001, The History and Role of Cooperatives. Mimeo. University of Wisconsin. Center for Cooperatives.

Danmarks Mejeri-drifts-statistik 1898-1904. Kontoret for Mejeri-statistik Aarhus.

DiGiuseppe, Gary, 2010. Dairy Coops http://www.americandairymen.com

Dyrbye, E. 1954, Retsforholdet mellem andelsforeninger og deres medlemmer. Fællesbanken for Danmarks Sparekasser, København. 
Fernández, Eva, 2010, Determinants of Agricultural Co-operatives in the Western World, 18801930. Mimeo. Department of Economic History and Institutions, Universidad Carlos III de Madrid.

Fonterra Co-operative Group Ltd. http://www.referenceforbusiness.com/history2/48/FonterraCo-operative-Group-Ltd.html

Goddard, Ellen, 2002, Factors Underlying the Evolution of farm-related Cooperatives in Alberta. Canadian Journal of Agricultural Economics 50, pp. 273-295.

Guinnane, T. 1994, 'A Failed Institutional Transplant: Raiffeisen's Credit Cooperatives in Ireland, 1894-1914', Explorations in Economic History 31, 38-61

Guinnane, T. 2005, 'Trust: A Concept too Many', Economic Growth Center, Yale University, Paper No. 907

Guinnane, Timothy W., 2010, New law for new enterprises: the development of cooperative law in Germany, 1867-1889. Mimeo. Yale University.

Hansmann, H., 2000, The Ownership of Enterprise. Cambridge, MA.: The Belknap Press of Harvard University Press

Hanssen, H.P., 1930, Et Tilbageblik II 1888-1906, Copenhagen: Gyldendal

Henriksen, I., 1999, 'Avoiding Lock-In: Co-operative Creameries in Denmark, 1882-1903', European Review of Economic History 3, 57-78.

Henriksen, I. and M. Hviid, 2005, Diffusion of new technology and complementary bets practice: A case study. European Review of Economic History. Vol. 9. Part 3, 365-397.

Henriksen, I., M. Lampe and P. Sharp, 2011, The Role of Technology and Institutions for Growth: Danish Creameries in the late Nineteenth Century. European Review of Economic History, forthcoming.

Henriksen, I. and K. H. O'Rourke. 2005, 'Incentives, technology, and the shift to year-round dairying in late nineteenth-century Denmark. Economic History Review. Vol. LVIII, no. 3, 520545.

Hoare, Samuel, 1889, Butter Making in Denmark, a paper read before the Norfolk Chamber of Agriculture at Norwich Saturday January 5th 1889. The Norfolk Chronicle co. Ltd. 
Hviid, M., 2001, 'Incentive Payments in Danish Cooperative Dairies'. Advances in the Economic Analysis of Participatory and Labor-managed Firms. Vol. 9 149-176.

Hørlyck, E. 2000, Dansk andelsret. 3.udg. Jurist- og Økonomforbundets Forlag, København Johansen, H.Chr., 1985, Dansk historisk statistik 1814-1980. Gyldendal, København.

Kindleberger, C. 1951. Group behaviour and international trade. Journal of Political Economy Kyed, J., 1910, Enkelte statistiske Oplysninger vedrørende Mejeribruget. Kontoret for Mejeristatistik, Odense

La Porta, R., Lopez-de-Silanes, F., Shleifer, A. and Vishny, R.W. 1997, 'Trust in large organizations', American Economic Review Papers and Proceedings, 87:2, 333-8

La Porta, Rafael, Florencio Lopez-de-Silanes, and Andrei Shleifer, 2008, The Economic Consequences of Legal Origins. Journal of Economic Literature 46:2, pp. 285-332.

La Porta, Rafael, Florencio Lopez-de-Silanes, Andrei Shleifer, and Robert W. Visny, 1998, Law and Finance. Journal of Political Economy, vol. 106, no. 6, pp. 1113-1155.

Lawless, Greg, 2002, History of Cooperatives in Wisconsin. University of Wisconsin. Center for Cooperatives. Bulletin No. 2.

Masten, S., 2000, Contractual Choice in B. Boukart and G. De Geest (eds.) Encyclopedia of Law and Economics, vol.III, Cheltenham: Edward Elgar, pp.25-45.

McCabe, D. 1906 'The Recent Growth of Co-operation in Ireland', Quarterly Journal of Economics, 20, 547-574.

Ó Gráda, C., 1977, 'The beginning of the Irish creamery system, 1880-1914', Economic History Review 30, 284-305.

O'Rourke, K,.H., 2002. 'Culture, Politics and Innovation: Evidence from the Creameries', CEPR Discussion Paper no. 3235. London, Centre for Economic Policy Research.

O'Rourke, K.H. 2007, 'Culture, conflict and cooperation: Irish dairying before the Great War', Economic Journal 117:523, 1357-1379

Pedersen, M.C., 1895 (1981 edition by Claus Bjørn) Andelsmælkerivirksomheden i Vestjylland 1884-85. Esbjerg: Syddjysk Universitetsforlag.

Rashid, S. 1988, 'Quality in Contestable Markets: A Historical Problem?', The Quarterly Journal of Economics, 103:1, 245-249 
Rey, P. and Tirole, J. 2000, 'Loyalty and Investment in Cooperatives', IDEI Workings Papers 123, Toulouse

Rommes, Ronald, 2008. The rise of Agricultural Cooperatives in the Netherlands. Mimeo, Wageningen University.

Schriver, D.H., 2005, Cooperatives In the Dairy Industry. United states Department of Agriculture. Rural Development, Cooperative Information, Report 1, Section 16.

Statistiske Meddelelser 1911, 4. række 36. bind. København.

Statistiske Meddelelser 1914, 4. række, 40. bind. København.

U.S. Department of Agriculture, 1958, Agriculture Handbook no. 138.

Williamson, O.E., 1989. Transaction cost economics. In R. Schmalensee and R.D. Willig (eds.), Handbook of Industrial Organization I. Amsterdam: North Holland.

Williamson, O.E., 1998. 'Transaction Cost Economics: How It Works; Where It Is Headed', De Economist, 146:1, 23-58

Williamson, O.E., 2000. 'The New Institutional Economics: Taking Stock, Looking Ahead', Journal of Economic Literature, 38:3, 595-613 